\title{
Impact of Two Functional Progesterone Receptor Polymorphisms (PRP): +331G/A and PROGINS on the Cancer Risks in Familial Breast/Ovarian Cancer
}

\author{
Andrea Romano ${ }^{1,2}$, Marleen Baars ${ }^{3}$, Herman Martens ${ }^{3}$, Rita Brandao ${ }^{2,3,4}$, Yvonne Detisch ${ }^{3}$, Eveline \\ Jongen $^{3}$, Marinus J. Blok ${ }^{3}$, Patrick Lindsey ${ }^{4}$, Dagmar-C. Fischer ${ }^{5}$ and Encarna B. Gómez García*,2,3 \\ ${ }^{I}$ Department of Obstetrics and Gynecology, University Hospital of Maastricht. (NL) \\ ${ }^{2}$ Research Institute Growth and Development (GROW), University Hospital of Maastricht. (NL) \\ ${ }^{3}$ Department of Clinical Genetics, University Hospital of Maastricht. (NL) \\ ${ }^{4}$ Department of Population Genetics, University and University Hospital of Maastricht, The Netherlands (NL). \\ ${ }^{5}$ Present address: Department of Pediatrics, Experimental Nephrology, Rostock University Medical Centre, Rostock, \\ Germany.
}

Abstract: Background: More than half of the families with breast and/or ovarian cancer (BC/OC) have no $B R C A 1$ or $B R C A 2$ mutation, moreover the broad lifetime risks reported within families with a BRCA1/2 mutation suggest other genes are also responsible.

Objective: Assess the prevalence, gene-gene and phenotype-genotype associations of two functional progesterone receptor polymorphisms (PRP), PROGINS and $+331 \mathrm{G} / \mathrm{A}$, in familial BC/OC.

Methods: DNA samples from 318 randomly selected probands tested for $B R C A 1 / 2$ mutations were genotyped for the $P R P$ and $C H E K 2 * 1100 \mathrm{delC}$ variant.

Results: $B R C A 1$ was associated with $\mathrm{BC}$ at young age, $\mathrm{p}=0.002 ;+331 A$ marginally with $\mathrm{OC}, \mathrm{p}=0.07$, and PROGINS with male $\mathrm{BC}, \mathrm{p}=0.04$. Homozygous $+331 \mathrm{~A} / \mathrm{A}$ co-segregated with $B R C A 2$ variants more frequently than expected by chance alone. Co-occurrence of $+331 A$ with a BRCA1BRCA2 mutation was associated with multiple $\mathrm{BC}$ events compared to $+331 A$ or $B R C A 1 / B R C A 2$ alone, $\mathrm{p}=0.02$.

Conclusions: The PRP are risk factors for familial BC/OC, and $+331 A$ allele is a gene modifier of BRCA1 and BRCA2.

\section{INTRODUCTION}

More than $50 \%$ of the families with $\mathrm{BC}$ and $\mathrm{OC}$ do not have mutations in the BRCA1 and BRCA2 genes [1-4]. So far, linkage analyses have failed in identifying new high penetrant genetic risk-factors responsible for the familial aggregation of those malignancies. It is hypothesized that the genetic basis in the remaining cases is highly heterogeneous [3-6] and that genes involved are low penetrant such as the CHEK2*1100delC variant $[7,8]$. In addition, within families with a mutation in BRCA1 or BRCA2, several lines of evidence suggest that additional genetic risk-factors/modifiers are present. For example, no current explanation exists for the fact that: i) in families with the same $B R C A 1$ or $B R C A 2$ mutation, some individuals develop $\mathrm{BC}$, some $\mathrm{OC}$, and others develop either both cancers or none; and ii) for the broad life-time risks for breast and OC reported among carriers of the same BRCA1 or BRCA2 mutation (Stanford Comprehensive Cancer Center statistics; http://cancer.stanford.edu/). Recent evidence for genetic modifiers have been provided by Smith and colleagues, who showed that women who tested negative for the familial BRCA1/BRCA2 mutation do have an increased risk for $\mathrm{BC}$ compared to the general population [9].

*Address correspondence to this author at the Department of Clinical Genetics, Maastricht University Medical Center, P.O. box 5800, 6202 AZ Maastricht, The Netherlands; Tel: +31 - 43 - 3875855; Fax: +31 - 43 - 3875800; E-mail: Encarna.Gomezgarcia@gen.unimaas.nl
Despite the fact that the DNA-repair action of BRCA1 and BRCA2 proteins is ubiquitous across the human tissues, it is noteworthy that their inactivation leads predominantly to cancer of the breast and ovaries. In these tissues, cell homeostasis is mainly controlled by steroid hormones (estrogen and progesterone) and their respective receptors. Furthermore, it has recently been shown that a progesterone antagonist prevents $B R C A 1$-mediated breast tumorigenesis in a mousemodel [10]. It is therefore plausible that genetic variants modifying the action of steroid hormone receptors might modify, alone or in combination with other risk-factors, the risk for $\mathrm{BC}$ and $\mathrm{OC}$.

The progesterone receptor (PR) has two isoforms, PRA and $\mathrm{PRB}$, which mediate all major responses to progesterone such as proliferation in the breast (mediated mainly through PRB [11]), and apoptosis in the ovarian epithelium (through PRA [12]).

Two functional $P R$ gene polymorphisms (PROGINS and $+331 \mathrm{G} / \mathrm{A}$ ) have been identified. PROGINS is a haplotype of three genetic variations in complete linkage disequilibrium: G3432T (Val660Leu substitution), C3764T (silent, His770His), and a HS-1/PV Alu insertion in intron G. PROGINS has a frequency of 0.12-0.16 among Caucasians [13-15] and reduces the activity of both PRA and PRB [16]. In case of the $+331 \mathrm{G} / \mathrm{A}$ promoter polymorphism [13], the rare allele $+331 \mathrm{~A}$ (with a frequency of 0.06-0.08 among 
Table 1. List of BRCA1 and BRCA2 Sequence Variants

\begin{tabular}{|c|c|c|c|c|}
\hline Type of variant & Exon number & Genetic change & Protein change & probands \\
\hline \multicolumn{5}{|l|}{$B R C A 1$} \\
\hline UV & 11 & $1377 \mathrm{~g}>\mathrm{t}$ & Asp420Tyr & 1 \\
\hline UV & 11 & $1998 \mathrm{~g}>\mathrm{a}$ & Val627Ile & 1 \\
\hline Trunc. Mut. & 11 & 2312del5 & STOP CODON 737 & 2 \\
\hline UV & 11 & $2596 c>a$ & Thr826Lys & 1 \\
\hline Trunc. Mut. & 11 & $2841 \mathrm{~g}>\mathrm{t}$ & STOP CODON 908 & 2 \\
\hline Trunc. Mut. & 11 & 3109 ins-aa & STOP CODON 1000 & 1 \\
\hline Trunc. Mut. & 22 & $5464 \mathrm{~g}>\mathrm{a}$ & STOP CODON 1782 & 2 \\
\hline Trunc. Mut. & 24 & $5622 c>t$ & STOP CODON 1835 & 1 \\
\hline \multicolumn{5}{|l|}{ BRCA2 } \\
\hline Trunc. Mut. & 5 & 697 del-aa & STOP CODON 182 & 1 \\
\hline Trunc. Mut. & 6 & IVS $6+1 \mathrm{~g}>\mathrm{t}$ & Frameshift & 1 \\
\hline UV & 10 & $1628 \mathrm{a}>\mathrm{g}$ & Lys467Arg & 1 \\
\hline UV & 11 & $3482 a>g$ & His1085Arg & 1 \\
\hline UV & 12 & IVS12-3 $t>c$ & in frame del. (32 aa) & 1 \\
\hline Trunc. Mut. & 16 & 7962 del- 6 ins- 9 & STOP CODON 2579 & 1 \\
\hline Trunc. Mut. & 17 & IVS16-1 $\mathrm{g}>\mathrm{t}$ & Frameshift & 1 \\
\hline UV & 21 & $8967 \mathrm{c}>\mathrm{g}$ & Asp2913Glu & 1 \\
\hline Trunc. Mut. & 23 & 9345 g>a (alt. spl.) & EXON 23 DEL. & 1 \\
\hline Trunc. Mut. & 18 & 8286 del-t & STOP CODON 2693 & 1 \\
\hline
\end{tabular}

UV: unclassified variant; Trunc. Mut.: protein truncating mutation; del.: deletion; ins: insertion; alt. spl.: alternative splicing; IVS: splice junction variant.

Caucasians) increases the relative PRB/PRA expression compared to $+331 G$. Both polymorphisms have been shown to modify the risk for breast [2, 17-19] and OC [14, 15, 17, $20,21]$ in several case-control studies. However these associations were not confirmed by other studies [13, 17, 22-26]. The role of these $P R$ variants in the pathogenesis of familial $\mathrm{BC}$ and $\mathrm{OC}$ is largely unknown.

The aim of our study is to evaluate the role of $+331 A$ and PROGINS as risk-factors for familial $\mathrm{BC}$ and $\mathrm{OC}$, alone or in combination with sequence variants in the BRCAl and
BRCA2 genes or with $C H E K 2 * 1100 d e l C$. We studied the prevalence, the genotype-tumor phenotype associations and the gene-gene interactions in a population of randomly selected probands who were tested for $B R C A 1$ and $B R C A 2$ mutations because of a family history of $\mathrm{BC}$ and $\mathrm{OC}$.

\section{MATERIALS AND METHODOLOGY}

\section{Study Population}

Three-hundreds and eighteen (318) probands (men and women) were randomly selected from a DNA bank of pa- 
tients that had been tested for $B R C A 1$ and $B R C A 2$ mutations because of a personal/family history of $\mathrm{BC}$ and/or $\mathrm{OC}$ at our Department of Clinical Genetics. All probands originated from the Southern region of the Netherlands (Limburg and Brabant) and had been counseled at our Cancer Genetics Service. The study was approved by the Medical Ethics Committee of the hospital. From the 318 individuals, 29 were already deceased at the time of the study, and 191 gave written informed consent to retrieve clinical and family data from their medical records. This group (220 individuals) will be indicated as CF-group (Clinical Features), to distinguish it from the whole population $(n=318)$. Among the CF-group, 12 women had not been diagnosed with any cancer but had been tested because none of the affected relatives was still alive.

\section{Genetic Analysis}

BRCA1 and BRCA2: DNA extraction and genetic analysis of $B R C A 1$ and $B R C A 2$ mutations have been already described [27]. Mutation screening included the whole coding sequence plus splice junctions of the BRCA1 and BRCA2 genes. The term 'sequence variants' in the present study refers to both genetic unclassified variants (UVs) and truncating mutations (Table 1). In addition, a number of rare polymorphisms previously classified as UVs found amongst the probands are also listed in Table 1. Results of BRCA1 and $B R C A 2$ screening were revealed only after the genotyping for the other three genetic markers was completed.

Progesterone receptor $(P R)$ polymorphisms: PROGINS (A1/A2; Reference SNP Cluster Report: rs1042838 ${ }^{1}$ and rs $1042839^{2}$ and NCBI Z49816 ${ }^{3}$ ) and +331 G/A (rs10895068) detection was performed by restriction fragment length polymorphism analysis [15]. Analyses were performed twice to reduce the risk of miss-genotyping. With respect to the PROGINS polymorphism, only the V660L substitution in exon 4 (G3432T) was genotyped and used to assess the presence or the absence of the PROGINS allele. Al refers to the most common allele, $A 2$ to PROGINS.

CHEK2*1100delC: was detected by PCR, followed by DNA sequence analysis. Exon 10 of the CHEK2 gene was amplified using specific primers: 5' GCAAGTTCAACATTATTCCCTTTT (forward) and 5' ATCACCTCCTACCAGCCTGTGC (reverse). The PCR reaction was performed using the Taq polymerase (Invitrogen, Life Technologies, Inc., Carlsbad, CA) as recommended by the manufacturer with $33 \mathrm{ng}$ of genomic DNA. PCR conditions consisted of 6 touch-down cycles (annealing temperature from $64^{\circ} \mathrm{C}$ to $60.5^{\circ} \mathrm{C}$ ) and $72^{\circ} \mathrm{C} / 45 \mathrm{sec}$ of elongation, followed by 30 extra cycles $\left(94^{\circ} \mathrm{C} / 30 \mathrm{sec}, 60.5^{\circ} \mathrm{C} / 30 \mathrm{sec}\right.$ and $\left.72^{\circ} \mathrm{C} / 45 \mathrm{sec}\right)$. The PCR products (245bp) were sequenced using the BigDye Terminator kit 1.1 (Applied Biosystems, Warrington Cheshire, UK) and the ABI3100 sequencer.

\section{Statistical Analysis}

Genetic clustering: expected numbers of probands in which more than one genetic variant co-occurred were

${ }^{1}$ rs1042838 refers to the G3432T in exon 4, Val660Leu. Nucleotide position is based on cDNA counting, NCBI X51730.

${ }^{2}$ rs 1042839 refers to the $\mathrm{C} 3764 \mathrm{~T}$ in exon 5 His770His.

${ }^{3} \mathrm{NCBI}$ Z49816 corresponds the HS-1/PV Alu insertion in intron G.

NCBI Reference SNP Cluster Report: http://www.ncbi.nlm.nih.gov/entrez estimated based on the frequency of each variant in the study population. Expected number and observed numbers were compared using a log-linear model.

Gene-phenotype correlations: were assessed by Fisher's exact test in the CF-group.

\section{RESULTS}

\section{Genotype Distribution}

The present study includes 318 randomly selected probands tested for $B R C A 1$ and $B R C A 2$ mutations because of a family history of breast or OC. Table 2 shows the allele frequencies of each of the genetic parameters investigated. The two $P R$ polymorphisms and the $C H E K 2 * 1100$ delC variant were in Hardy-Weinberg equilibrium (not shown).

Table 2. Prevalence of PROGINS (A2), +331A $C H E K 2 * 1100 d e l C$ Variant, BRCA1 and BRCA2 Sequence Variants

\begin{tabular}{|c|c|c|}
\hline $\operatorname{PROGINS}(\mathrm{n}=296)^{\mathrm{a}}$ & $\mathbf{n}$ & $(\%)$ \\
\hline$A 1 / A 1$ & 222 & $(75.0)$ \\
\hline$A 1 / A 2$ & 68 & $(23.0)$ \\
\hline$A 2 / A 2$ & 6 & $(2.0)$ \\
\hline all. frequency & A1 & 0.86 \\
\hline all. frequency & A2 & 0.14 \\
\hline$+331 G / A(\mathrm{n}=298)^{a}$ & $\mathbf{n}$ & $(\%)$ \\
\hline$G / G$ & 264 & (88.6) \\
\hline$G / A$ & 32 & $(10.7)$ \\
\hline$A / A$ & 2 & $(0.7)$ \\
\hline all. frequency & $331 \mathrm{G}$ & 0.94 \\
\hline all. frequency & $331 \mathrm{~A}$ & 0.06 \\
\hline CHEK2 $(\mathrm{n}=278)^{\mathrm{a}}$ & $\mathbf{n}$ & $(\%)$ \\
\hline wild-type/wild-type & 267 & $(96.0)$ \\
\hline *1100delC/wild-type & 11 & $(4.0)$ \\
\hline$* 1100 \mathrm{delC} / * 1100 \mathrm{delC}$ & 0 & $(0.0)$ \\
\hline all. frequency & wild-type & 0.98 \\
\hline all. frequency & $* 1100 \mathrm{delC}$ & 0.02 \\
\hline $\operatorname{BRCA1} / \mathrm{BRCA2}(\mathrm{n}=318)^{\mathrm{a}}$ & $\mathbf{n}$ & $(\%)$ \\
\hline wild-type & 262 & $(82.4)$ \\
\hline$B R C A l$ variant & 21 & (6.6) \\
\hline$B R C A 2$ variant & 35 & $(11.0)$ \\
\hline
\end{tabular}

a: number of individuals successfully screened for the indicated genetic factor.

Two-hundred-seventy-eight (278) individuals were successfully screened for all the genetic factors. Fig. 1 displays their genotypic distribution. None of the patients who carried a genetic variant in the $B R C A 1$ or $B R C A 2$ gene, carried also the $C H E K 2 * 1100$ delC variant. On the contrary, PROGINS and $+331 A$ were present both among BRCA1 and BRCA2 sequence variant carriers as in the $B R C A 1$ and $B R C A 2$ wildtype group Fig. 1. In particular, the co-occurrence of homozygous $+331 A / A$ and $B R C A 2$ mutations was significantly higher than expected by chance alone (observed number $=1$, 


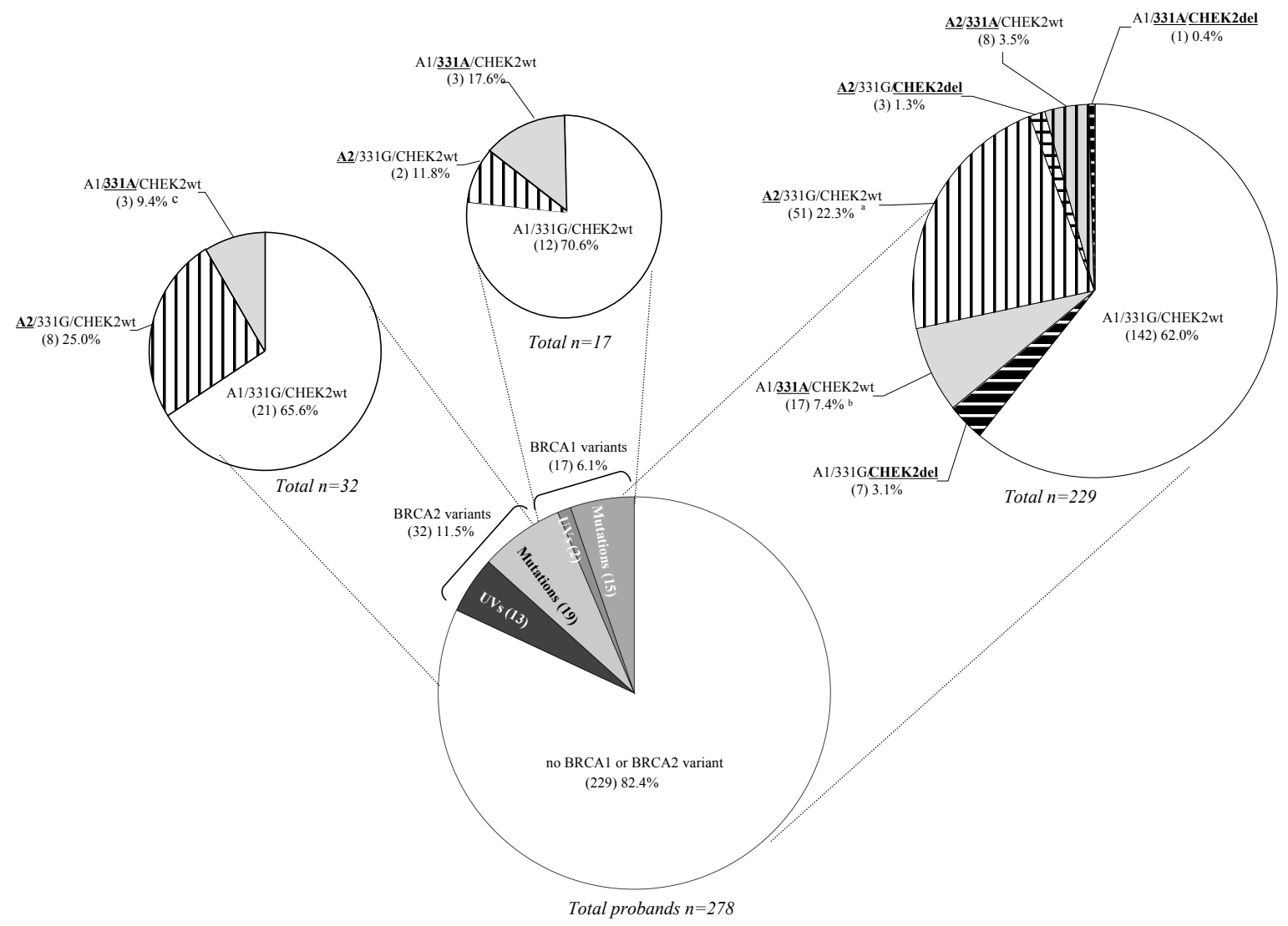

Fig. (1). Genotype distribution and co-occurrence of more than one rare genetic variant in the population.

Genotype distribution is represented in I) the whole population (circle at the bottom); II) carriers of a sequence variant in the $B R C A 1$ gene (above middle); III) carriers of a sequence variant in the BRCA2 gene (left), and IV) BRCA1 and BRCA2 wild-type carriers (circle at the right).

Unless specified in the footnotes, probands were heterozygous for the genetic variant under consideration.

a: Five of 51 probands were $A 2 / A 2$ and 46 were $A 1 / A 2$.

b: Sixteen of the 17 probands were $+331 G / A$ and one was $+331 A / A$.

c: Two of the three probands were $+331 G / A$ and one was $+331 A / A$.

expected number $=0.078$, ratio $($ obs/exp $)=12.8,95 \%$ $\mathrm{CI}=1.8-91.0$; log-linear model). The only other case with a homozygous +331A/A observed in this series did show a rare polymorphism in the BRCA2 gene: Lys2950Asn.

\section{Clinical Characteristics}

Clinical information was available from 220 patients (i.e. CF group). The majority of the CF-group (187/220; 6 men and 181 women) had been diagnosed with BC. From these, 21 women had primary BC twice (ipsi- or contralateral) and 24 were diagnosed with epithelial OC. Three of these 24 women also developed BC. Twelve women had not been diagnosed with any cancer. The inclusion criteria for BRCA1 and $B R C A 2$ genetic diagnosis (indication for DNA analysis) and additional clinical features are also described in Table 3.

The 220 probands belonged to 214 independent families including 3949 first and second-degree family members [2087 (52.8\%) female, $1721(43.6 \%)$ male and $148(3.6 \%)$ of unknown gender]. Over $95 \%$ of the families (204/214) presented at least one case of BC (maximum 6 cases; average age at diagnose: 51.1 \pm 9.9 ) and about half of the families
(109/214) had three or more relatives with BC (including the proband). A total of 564 relatives with $\mathrm{BC}$ were recorded. Twenty-nine families $(0.7 \%)$ presented at least one patient with two primary breast cancers.

About one quarter of the families $(51 / 214,23.8 \%)$ had at least one case of OC and 19 families $(9.0 \%)$ had two or more cases of OC (maximum 4 cases; average age at diagnose: $53.7 \pm 13.6)$. A total of 78 relatives having OC were recorded. Cancers at sites other than breast and ovaries were seen in half of the families: colon cancer (70 cases), lung cancer $(n=27)$, prostate cancer $(n=19)$, gastric cancer $(n=15)$, skin cancer $(n=14)$, brain tumors $(n=12)$, pancreatic cancer $(n=11)$, ORL cancer $(n=11)$, cervical cancer $(n=5)$, leukemia $(n=5)$, bladder cancer $(n=4)$, other cancers $(n=47)$.

\section{Genotype Phenotype Correlations (Table 4)}

\section{III-a. PROGINS PR Polymorphism}

The PROGINS allele (A1/A2 or A2/A2) was significantly more frequent among male compared to female probands, 
Table 3. Clinical Characteristics of the Probands (CF-Group, $\mathbf{n}=\mathbf{2 2 0}$ )

\begin{tabular}{|c|c|}
\hline & $\mathbf{n}(\%)$ \\
\hline \multicolumn{2}{|l|}{ Breast cancer } \\
\hline Yes & $187^{\mathrm{a}}(85.0)$ \\
\hline No & $33(15.0)$ \\
\hline Age of breast cancer onset (mean \pm SD) & $47.3 \pm 11.1^{\mathrm{b}}$ \\
\hline \multicolumn{2}{|l|}{ Breast cancer twice } \\
\hline Yes & $21(11.2)$ \\
\hline No & $166(88.8)$ \\
\hline Age of second breast cancer onset (mean \pm SD) & $51.0 \pm 9.9$ \\
\hline \multicolumn{2}{|l|}{ Ovarian cancer } \\
\hline Yes & $24(11.2)$ \\
\hline No & $190(88.8)$ \\
\hline Age of ovarian cancer onset $($ mean \pm SD) & $52.4 \pm 15.1$ \\
\hline \multicolumn{2}{|l|}{ Histology of ovarian cancer } \\
\hline I-1 Epithelial serous & $8(33.3)$ \\
\hline I-2 Epithelial mucinous & $6(25.0)$ \\
\hline I-3 Epithelial endometrioid & $1(4.2)$ \\
\hline I-4 Epithelial Brenner & $1(4.2)$ \\
\hline Unknown & $8(33.3)$ \\
\hline \multicolumn{2}{|l|}{ Other cancer (no breast and ovary) ${ }^{c}$} \\
\hline Yes & $12(5.5)$ \\
\hline No & $208(94.5)$ \\
\hline \multicolumn{2}{|l|}{ Indication for DNA analysis } \\
\hline \multicolumn{2}{|l|}{ I. One first degree relative diagnosed with: } \\
\hline I.a. breast cancer below 35 years & $10(5.3)$ \\
\hline $\begin{array}{l}\text { I.b. bilateral breast cancer. First is } \\
\text { premenopausal }\end{array}$ & $4(2.1)$ \\
\hline I.c. male breast cancer & $3(1.6)$ \\
\hline \multicolumn{2}{|l|}{$\begin{array}{l}\text { II. Two first or second degree relatives diag- } \\
\text { nosed with: }\end{array}$} \\
\hline $\begin{array}{l}\text { II.a. breast or ovarian cancer before } \\
\text { menopause }\end{array}$ & $50(26.7)$ \\
\hline II.b. ovarian cancer (only first degree) & $3(1.6)$ \\
\hline III. Three or more patients in the family & $111(59.4)$ \\
\hline IV. Pre-symptomatic ${ }^{{ }^{\mathrm{d}}}$ & $1(0.5)$ \\
\hline V. Unknown & $5(2.7)$ \\
\hline
\end{tabular}

abreast cancer patients include 6 men.

b the average age of breast cancer in man onset was $59.0 \pm 6.6$.

'other sites of cancer onset were colon $(n=2)$, brain $(n=3)$, melanoma $(n=4)$, pancreas $(\mathrm{n}=1)$, (mesothelioma in peritoneum, $\mathrm{n}=1)$ and one ORL cancer. All women presenting cancer at sites other than breast or ovary were also diagnosed with breast $(n=11)$ or ovarian $(n=1)$ cancer.

dpresymptomatic indicates that the variant in $B R C A 1$ or $B R C A 2$ was already known in the family. both in the whole group $(\mathrm{n}=220 ; \mathrm{p}=0.047)$ and among patients diagnosed with $\mathrm{BC}(\mathrm{n}=167 ; \mathrm{p}=0.04)$. Further, patients carrying the PROGINS allele did not differ significantly with respect to any of the other investigated clinical or histological features.

\section{III-b. +331G/A PR Polymorphism}

Patients carrying the $+331 \mathrm{~A}$ allele were diagnosed more frequently with two primary $\mathrm{BC}$ and with OC than noncarriers. These differences were of borderline significance $(\mathrm{p}=0.09$ and 0.07 , respectively; Table 4).

\section{III-c. CHEK2*1100delC Variant}

All CHEK2*1100delC carriers were women with $\mathrm{BC}$, none of them had OC (Table 4). Further, no other clinical or histological features investigated was influenced by the presence of this variant.

\section{III-d. BRCAI Mutations}

Patients carrying a mutation in the BRCAl gene were significantly younger when BC was diagnosed $(\mathrm{p}=0.002)$. When also BRCA1 UVs were considered, results did not change ( $\mathrm{p}=0.028$; results not shown).

\section{III-e. BRCA2 Mutations}

Patients carrying a mutation on the $B R C A 2$ gene did not differ from patients being $B R C A 2$ wild-type with respect to any of the clinical characteristics investigated.

\section{Gene-Gene Interactions}

To evaluate the effect of co-occurrence of genetic risk factors we looked for patients having unfavorable clinical characteristics, such as occurrence of both $\mathrm{BC}$ and $\mathrm{OC}, \mathrm{BC}$ twice, $\mathrm{BC}$ below the age of 40 years, or $\mathrm{OC}$ before the menopause and compared their frequency with the numbers of genetic risk alleles: none, one or two. The following combinations of genetic risk factors were investigated: $+331 \mathrm{~A}$ and BRCA1/2; PROGINS and BRCA1/2; +331A and PROGINS; CHEK2*1100delC and +331A; and CHEK2*1100delC and PROGINS. Only the combination: $+331 A$ and BRCA1/2 resulted in significant differences in the distribution of patients having unfavourable features $(p=0.02$; Table 5). Notably, no patient carrying both $+331 A$ and a mutation in the $B R C A 1$ or $B R C A 2$ gene was seen in the average feature group, whereas all three patients carrying both $+331 A$ and a $B R C A 1$ or $B R C A 2$ mutation belonged to the group of patients with unfavorable clinical features. One of those women was $+331 A / A$ homozygous and carried a mutation in the $B R C A 2$ gene, the other two women were $+331 G / A$ heterozygous and carried one BRCAl mutation each. All those three women were diagnosed twice with $\mathrm{BC}$.

\section{DISCUSSION}

Some case-control studies have suggested that PROGINS is protective against $\mathrm{BC}$ [2] but a risk-factor for $\mathrm{OC}[14,15$, 17], whereas the $+331 \mathrm{~A}$ allele appeared to be a risk-factor both for BC [19] and for OC [15, 21]. Other authors, however, did not find any association $[13,17,22-26,28]$. So far, the study of Runnebaum and coworkers [20] is the only one that investigates the effect of one of the $P R$ polymorphisms (PROGINS) on $\mathrm{BC}$ and OC risk among BRCA1 and BRCA2 carriers and reports that $P R O G I N S$ increases the risk for $\mathrm{OC}$ 
Table 4. Clinical Characteristics of the Genotypes

\begin{tabular}{|c|c|c|c|c|c|c|c|c|c|c|c|c|c|c|}
\hline & \multicolumn{7}{|c|}{ PROGINS } & \multicolumn{7}{|c|}{$+331 G / A$} \\
\hline & $\mathbf{n}$ & $(\%)$ & n & $(\%)$ & $\mathbf{n}$ & $(\%)$ & p value & $\mathbf{n}$ & $(\%)$ & $\mathbf{n}$ & $(\%)$ & $\mathbf{n}$ & $(\%)$ & $p$ value \\
\hline \multicolumn{15}{|l|}{ Gender } \\
\hline Male & 2 & $(40.0)$ & 2 & $(40.0)$ & 1 & $(20.0)$ & 0.0474 & 6 & (100) & 0 & $(0.0)$ & 0 & $(0.0)$ & 1.0000 \\
\hline Yes & 123 & (73.7) & 41 & $(24.6)$ & 3 & (1.8) & \multirow[t]{2}{*}{0.3150} & 153 & (90.5) & 15 & (8.9) & 1 & $(0.6)$ & \multirow{2}{*}{0.1092} \\
\hline No & 22 & (71.0) & 7 & $(22.6)$ & 2 & $(6.5)$ & & 25 & (80.6) & 5 & (16.1) & 1 & (3.2) & \\
\hline \multicolumn{15}{|c|}{ Gender BC } \\
\hline Male & 2 & $(40.0)$ & 2 & $(40.0)$ & 1 & $(20.0)$ & 0.0374 & 6 & $(100)$ & 0 & $(0.0)$ & 0 & $(0.0)$ & 1.0000 \\
\hline$>40$ & 88 & $(72.1)$ & 31 & $(25.4)$ & 3 & $(2.5)$ & 0.6802 & 112 & (89.6) & 12 & $(9.6)$ & 1 & $(0.8)$ & 0.8236 \\
\hline \multicolumn{15}{|l|}{ Two BCs } \\
\hline Yes & 14 & $(73.7)$ & 5 & $(26.3)$ & 0 & $(0.0)$ & \multirow{2}{*}{1.0000} & 16 & $(84.2)$ & 2 & $(10.5)$ & 1 & (5.3) & \multirow[t]{2}{*}{0.0887} \\
\hline No & 109 & $(73.6)$ & 36 & $(24.3)$ & 3 & $(2.0)$ & & 137 & (91.3) & 13 & (8.7) & 0 & $(0.0)$ & \\
\hline \multicolumn{15}{|l|}{ OC } \\
\hline Yes & 16 & $(72.7)$ & 6 & $(27.3)$ & 0 & $(0.0)$ & \multirow{2}{*}{0.8725} & 17 & $(77.3)$ & 4 & $(18.2)$ & 1 & $(4.5)$ & \multirow[t]{2}{*}{0.0736} \\
\hline No & 127 & (74.3) & 40 & (23.4) & 4 & $(2.3)$ & & 155 & $(90.1)$ & 16 & $(9.3)$ & 1 & (0.6) & \\
\hline
\end{tabular}

\begin{tabular}{|c|c|c|c|c|c|c|c|c|c|c|c|c|c|c|c|}
\hline & \multicolumn{5}{|c|}{ CHEK2*1100delC } & \multicolumn{5}{|c|}{ BRCA1 } & \multicolumn{5}{|c|}{ BRCA2 } \\
\hline & $\mathbf{n}$ & $(\%)$ & $\mathbf{n}$ & $(\%)$ & p value & $\mathbf{n}$ & $(\%)$ & $\mathbf{n}$ & $(\%)$ & p value & $\mathbf{n}$ & $(\%)$ & $\mathbf{n}$ & $(\%)$ & p value \\
\hline \multicolumn{16}{|c|}{ Gender } \\
\hline Male & 5 & $(100)$ & 0 & $(0.0)$ & 1.0000 & 6 & $(100)$ & 0 & $(0.0)$ & 1.0000 & 5 & $(83.3)$ & 1 & (16.7) & 0.2676 \\
\hline Yes & 148 & $(94.9)$ & 8 & $(5.1)$ & \multirow{2}{*}{0.6066} & 178 & $(95.2)$ & 9 & $(4.8)$ & \multirow{2}{*}{0.3959} & 178 & $(95.2)$ & 9 & $(4.8)$ & \multirow{2}{*}{0.6721} \\
\hline No & 27 & $(100)$ & 0 & $(0.0)$ & & 30 & $(90.9)$ & 3 & $(9.1)$ & & 31 & (93.9) & 2 & $(6.1)$ & \\
\hline \multicolumn{16}{|c|}{ BC Gender } \\
\hline Male & 5 & $(100)$ & 0 & $(0.0)$ & 1.0000 & 6 & $(100)$ & 0 & $(0.0)$ & 1.0000 & 5 & $(83.3)$ & 1 & (16.7) & 0.2592 \\
\hline$</=40$ & 34 & $(89.5)$ & 4 & $(10.5)$ & \multirow{2}{*}{0.2048} & 43 & $(86.0)$ & 7 & $(14.0)$ & \multirow{2}{*}{0.0016} & 49 & $(98.0)$ & 1 & $(2.0)$ & \multirow{2}{*}{0.4485} \\
\hline$>40$ & 114 & (96.6) & 4 & (3.4) & & 135 & (98.5) & 2 & $(1.5)$ & & 129 & $(94.2)$ & 8 & $(5.8)$ & \\
\hline \multicolumn{16}{|c|}{ Two BCs } \\
\hline Yes & 19 & $(89.5)$ & 2 & $(10.5)$ & \multirow{2}{*}{0.2520} & 20 & (90.9) & 2 & $(9.1)$ & \multirow{2}{*}{0.2862} & 21 & $(95.5)$ & 1 & $(4.5)$ & 10000 \\
\hline No & 137 & $(95.6)$ & 6 & (4.4) & & 158 & (95.8) & 7 & $(4.2)$ & & 157 & $(95.2)$ & 8 & $(4.8)$ & 1.0000 \\
\hline OC & & & & & & & & & & & & & & & \\
\hline Yes & 21 & (100) & 0 & $(0.0)$ & 05085 & 21 & $(87.5)$ & 3 & (12.5) & 01258 & 23 & $(95.8)$ & 1 & $(4.2)$ & 18000 \\
\hline No & 157 & $(94.9)$ & 8 & $(5.1)$ & & 181 & $(95.3)$ & 9 & $(4.7)$ & & 181 & $(95.3)$ & 9 & $(4.7)$ & \\
\hline
\end{tabular}


Table 5. Gene-Gene Interactions

\begin{tabular}{|c|c|c|c|c|c|c|c|}
\hline & \multicolumn{3}{|c|}{ AVERAGE FEATURES } & \multicolumn{4}{|c|}{ ADVERSE FEATURES (1) } \\
\hline & 116 & & & 73 & & & 0.0213 \\
\hline No variant (i.e. $331 \mathrm{G} / \mathrm{G}$ and BRCA1\&2 wild type) & & 98 & $(64.5)$ & & 54 & $(35.5)$ & \\
\hline BRCA1 or BRCA2 mutation & & 7 & $(38.9)$ & & 11 & $(61.1)$ & \\
\hline$+331 \mathrm{~A}$ and $\mathrm{BRCA} 1$ or BRCA2 mutation & & 0 & $(0.0)$ & & 3 & $(100)$ & \\
\hline
\end{tabular}

(1) the group of patients with unfavorable clinical features defined as: BC below 40 years $(n=39)$, OC before 55 years $(n=20)$, two BCs $(n=20)$ or BC and OC ( $n=2)$ in the same person.

in $B R C A 1 / 2$ mutation carriers who were never exposed to oral contraceptives.

In the present study, women carrying the PROGINS allele did not differ in the frequency of developing $\mathrm{BC}$ or OC compared to non-carriers. Interestingly, the PROGINS allele was significantly more frequent among men than among women diagnosed with $\mathrm{BC}$. Breast cancer in men is a rare disease whose etiology is largely unknown [8]. Though, it appears that steroid hormone imbalances are important epidemiological risk-factors also in male $\mathrm{BC}$ and more than $90 \%$ of breast tumors in man are PR positive [29]. The number of male patients with BC in our study $(n=6)$ was too small to draw any definitive conclusion, therefore, larger epidemiological studies are needed to confirm the role of PROGINS in male BC.

We observed a trend for an increased risk of OC and BC appearing twice among women carrying the $+331 \mathrm{~A}$ allele. The fact that those features were not significantly higher among BRCA1 and BRCA2 carriers may be due to insufficient statistical power, but may also reflect that $+331 A$ allele is a stronger predictor for both $\mathrm{OC}$ and multiple $\mathrm{BC}$ than $B R C A 1$ and $B R C A 2$.

We found evidence that suggest that the $+331 A$ allele in combination with $B R C A 1$ or $B R C A 2$ mutations have a synergistic effect. Firstly, the number of probands being homozygous $+331 A / A$ and carrying a mutation in the BRCA2 gene was significantly higher than in case they segregated independently. Interestingly the only two cases in this series who were homozygous $+331 A$ /A appeared to have either a mutation or a rare polymorphism in BRCA2. This additionally suggests that some rare polymorphisms are likely to be functional and to affect cancer risks. Secondly, a synergistic effect is further corroborated by the fact that all the patients carrying both $+331 A$ allele and a mutation in BRCA1 or $B R C A 2$ belonged to the group with specially unfavorable clinical features, and had multiple BC events in particular. A molecular explanation of this synergistic effect for BR risk can be due to the fact that the $+331 A$ allele, as a result of the increased PRB/PRA expression increases cell proliferation in the breast epithelium (mediated by PRB) in response to progesterone $[11,12]$. This, in combination with a defective DNA-repair machinery (due to a BRCA1 or BRCA2 variants), will facilitate the accumulation of cells with damaged DNA and, in turn, their malignant transformation.

\section{CONCLUSION}

In conclusion, we provide evidence that the $P R+331 A$ allele is a risk factor for familial $\mathrm{BC} / \mathrm{OC}$ and acts as gene modifier in families with a $B R C A 1$ or $B R C A 2$ sequence variant. If independently confirmed by others, genetic screening of the $+331 \mathrm{G} / \mathrm{A}$ polymorphism should be considered together with $B R C A 1$ and $B R C A 2$ mutation detection for an individual risk assessment of the probands and their relatives. Whether PROGINS will result into a prevalent risk factor for male BC, should be assessed in series including a larger number of men with $\mathrm{BC}$.

\section{LIST OF ABBREVIATIONS}

CI

UV

CHEK2

PROGINS = progesterone receptor intron $\mathrm{G}$ insertion

$\mathrm{CF}$ population $=$ clinical features population

$\mathrm{PRP} \quad=$ progesterone receptor polymophisms

$\mathrm{BC}=$ breast cancer

OC $=$ ovarian cancer

\section{ACKNOWLEDGEMENTS}

Ms. R. Brandao was supported by the Gulbenkian Foundation (Portugal). This study was supported by funds from the Maastricht University Hospital. We thank all patients involved in this study for their co-operation.

\section{REFERENCES}

[1] Antoniou AC, Pharoah PD, McMullan G, Day NE, Ponder BA, Easton D. Evidence for further breast cancer susceptibility genes in addition to BRCA1 and BRCA2 in a population-based study. Genet Epidemiol 2001; 21(1): 1-18.

[2] Dunning AM, Healey CS, Pharoah PD, Teare MD, Ponder BA, Easton DF. A systematic review of genetic polymorphisms and breast cancer risk. Cancer Epidemiol Biomarkers Prev 1999; 8(10): 843-54.

[3] Sutcliffe S, Pharoah PD, Easton DF, Ponder BA. Ovarian and breast cancer risks to women in families with two or more cases of ovarian cancer. Int J Cancer 2000; 87(1): 110-7.

[4] Houlston RS, Peto J. The search for low-penetrance cancer susceptibility alleles. Oncogene 2004; 23(38): 6471-6.

[5] Peto J. Breast cancer susceptibility-A new look at an old model. Cancer Cell 2002; 1(5): 411-2. 
[6] Pharoah PD, Antoniou A, Bobrow M, Zimmern RL, Easton DF, Ponder BA. Polygenic susceptibility to breast cancer and implications for prevention. Nat Genet 2002; 31(1): 33-6.

[7] Meijers-Heijboer H, van den Ouweland A, Klijn J, Wasielewski M, de Snoo A, Oldenburg R, Hollestelle A, Houben M, Crepin E, van Veghel-Plandsoen M, Elstrodt F, van Duijn C, Bartels C, Meijers C, Schutte M, McGuffog L, Thompson D, Easton D, Sodha N, Seal S, Barfoot R, Mangion J, Chang-Claude J, Eccles D, Eeles R, Evans DG, Houlston R, Murday V, Narod S, Peretz T, Peto J, Phelan C, Zhang HX, Szabo C, Devilee P, Goldgar D, Futreal PA, Nathanson KL, Weber B, Rahman N, Stratton MR. Lowpenetrance susceptibility to breast cancer due to CHEK2 $(*) 1100$ delC in noncarriers of BRCA1 or BRCA2 mutations. Nat Genet 2002; 31(1): 55-9.

[8] Weiss JR, Moysich KB, Swede H. Epidemiology of male breast cancer. Cancer Epidemiol Biomarkers Prev 2005; 14(1): 20-6.

[9] Smith A, Moran A, Boyd M, Bulman M, Shenton A, Smith L, Iddenden R, Woodward E, Lalloo F, Maher ER, Evans G. Phenocopies in BRCA1 and BRCA2 families: Evidence for modifier genes and implications for screening? J Med Genet 2006.

[10] Poole AJ, Li Y, Kim Y, Lin SC, Lee WH, Lee EY. Prevention of Brcal-mediated mammary tumorigenesis in mice by a progesterone antagonist. Science 2006; 314(5804): 1467-70.

[11] Conneely OM, Mulac-Jericevic B, Lydon JP. Progesteronedependent regulation of female reproductive activity by two distinct progesterone receptor isoforms. Steroids 2003; 68(10-13): 771-8.

[12] Ho SM. Estrogen, progesterone and epithelial ovarian cancer. Reprod Biol Endocrinol 2003; 1(1): 73.

[13] De Vivo I, Huggins GS, Hankinson SE, Lescault PJ, Boezen M, Colditz GA, Hunter DJ. A functional polymorphism in the promoter of the progesterone receptor gene associated with endometrial cancer risk. Proc Natl Acad Sci USA 2002; 99(19): 122638.

[14] Modugno F. Ovarian cancer and polymorphisms in the androgen and progesterone receptor genes: a HuGE review. Am J Epidemiol 2004; 159(4): 319-35.

[15] Romano A, Lindsey PJ, Fischer DC, Delvoux B, Paulussen AD, Janssen RG, Kieback DG. Two functionally relevant polymorphisms in the human progesterone receptor gene $(+331 \mathrm{G} / \mathrm{A}$ and progins) and the predisposition for breast and/or ovarian cancer. Gynecol Oncol 2006; 101(2): 287-95.

[16] Romano A, Delvoux B, Fischer D-C, Groothuis PG. The PROGINS polymorphism of the human progesterone receptor diminishes the response to progesterone. J Mol Endocrinol 2007; 38(1-2): 331350.

[17] Pearce CL, Hirschhorn JN, Wu AH, Burtt NP, Stram DO, Young S, Kolonel LN, Henderson BE, Altshuler D, Pike MC. Clarifying the PROGINS allele association in ovarian and breast cancer risk: a haplotype-based analysis. J Natl Cancer Inst 2005; 97(1): 51-9.

[18] Wang-Gohrke S, Chang-Claude J, Becher H, Kieback DG, Runnebaum IB. Progesterone receptor gene polymorphism is associated with decreased risk for breast cancer by age 50. Cancer Res 2000; 60(9): 2348-50.

[19] De Vivo I, Hankinson SE, Colditz GA, Hunter DJ. A functional polymorphism in the progesterone receptor gene is associated with an increase in breast cancer risk. Cancer Res 2003; 63(17): 5236-8.

[20] Runnebaum IB, Wang-Gohrke S, Vesprini D, Kreienberg R, Lynch H, Moslehi R, Ghadirian P, Weber B, Godwin AK, Risch H, Garber J, Lerman C, Olopade OI, Foulkes WD, Karlan B, Warner E, Rosen B, Rebbeck T, Tonin P, Dube MP, Kieback DG, Narod SA. Progesterone receptor variant increases ovarian cancer risk in BRCA1 and BRCA2 mutation carriers who were never exposed to oral contraceptives. Pharmacogenetics 2001; 11(7): 635-8.

[21] Risch HA, Bale AE, Beck PA, Zheng W. PGR +331 A/G and increased risk of epithelial ovarian cancer. Cancer Epidemiol Biomarkers Prev 2006; 15(9): 1738-41.

[22] Berchuck A, Schildkraut JM, Wenham RM, Calingaert B, Ali S, Henriott A, Halabi S, Rodriguez GC, Gertig D, Purdie DM, Kelemen L, Spurdle AB, Marks J, Chenevix-Trench G. Progesterone Receptor Promoter +331 A Polymorphism is Associated with a Reduced Risk of Endometrioid and Clear Cell Ovarian Cancers. Cancer Epidemiol Biomarkers Prev 2004; 13(12): 2141-7.

[23] Feigelson HS, Rodriguez C, Jacobs EJ, Diver WR, Thun MJ, Calle EE. No association between the progesterone receptor gene $+331 \mathrm{G} / \mathrm{A}$ polymorphism and breast cancer. Cancer Epidemiol Biomarkers Prev 2004; 13(6): 1084-5.

[24] Lancaster JM, Wenham RM, Halabi S, Calingaert B, Marks JR, Moorman PG, Bentley RC, Berchuck A, Schildkraut JM. No relationship between ovarian cancer risk and progesterone receptor gene polymorphism in a population-based, case-control study in North Carolina. Cancer Epidemiol Biomarkers Prev 2003; 12(3): 226-7.

[25] Terry KL, De Vivo I, Titus-Ernstoff L, Sluss PM, Cramer DW. Genetic variation in the progesterone receptor gene and ovarian cancer risk. Am J Epidemiol 2005; 161(5): 442-51.

[26] Fabjani G, Tong D, Czerwenka K, Schuster E, Speiser P, Leodolter $\mathrm{S}$, Zeillinger R. Human progesterone receptor gene polymorphism PROGINS and risk for breast cancer in Austrian women. Breast Cancer Res Treat 2002; 72(2): 131-7.

[27] Gómez García EB, Ambergen T, Blok MJ, van den Wijngaard A. Patients with an unclassified genetic variant in the BRCA1 or BRCA2 genes show different clinical features from those with a mutation. J Clin Oncol 2005; 23(10): 2185-90.

[28] Pooley KA, Healey CS, Smith PL, Pharoah PD, Thompson D, Tee L, West J, Jordan C, Easton DF, Ponder BA, Dunning AM. Association of the progesterone receptor gene with breast cancer risk: a single-nucleotide polymorphism tagging approach. Cancer Epidemiol Biomarkers Prev 2006; 15(4): 675-82.

[29] Murphy CE, Carder PJ, Lansdown MR, Speirs V. Steroid hormone receptor expression in male breast cancer. Eur J Surg Oncol 2006; 32(1): 44-7. 